\title{
Sustainability in higher education from the perspective of business ethics and corporate sustainability
}

\section{LUc VAN LIEDEKERKE}

\section{University of Antwerp \& University of Leuven, Belgium}

\begin{abstract}
:
Aim: In this epilogue to the special issue, the author provides a reflection on the commonalities between the origins of business ethics and corporate sustainability on the one hand, and Higher Education for Sustainable Development on the other hand.
\end{abstract}

Design / Research methods: The paper is reflective and provides future avenues to further develop the fields of business ethics, corporate sustainability, and Higher Education for Sustainable Development.

Conclusions / findings: Although both fields developed independently, they share the same focus on interdisciplinary studies, integrated thinking, and looking beyond the short term and local interests.

Originality / value of the article: In the end, both disciplines are carried by a fundamental normative choice for an inclusive, sustainable society, a choice that should never be forgotten and is the horizon of all our research.

Key words: business ethics, corporate sustainability, higher education for sustainable development, interdisciplinary approaches

JEL: I23, M14, Q01, Q56

Correspondence address: Luc Van Liedekerke, University of Antwerp, Antwerpen, Belgium. E-mail: luc.vanliedekerke@ uantwerpen.be

Received: 22.08.2019, Accepted: 28.08.2019

doi: http://dx.doi.org/10.29015/cerem. 853 


\section{Introduction}

The British historian Tawney - well known for his study on the origin of the market - describes the medieval market as a place of usury and monopoly and it is therefore not surprising that for centuries vices instead of virtues were situated at the heart of the market (Tawney 1998). Even contemporary business ethicist David Vogel notes with almost Medieval indignation that three of the seven deadly sins, namely greed, envy and gluttony, are necessary for the well-functioning of the market (Vogel 2005). Business ethics is an oxymoron and the market is per definition an a-moral system in which people are driven by greed, and which can only be restricted through strict regulation. It is a popular view about the market, with which each business ethics teacher is confronted (preferably during the first lesson), and a public cliché that finds support in the post-war Western thinking about the market and its actors.

The dual conception of market versus state in which economic actors (consumers, producers) do not have to think about their moral action is a central theme in the post-war thinking, both on the left as on the right of the (political, economic, academic) spectrum. Neomarxist thinkers as Jurgen Habermas, Niklass Luhmann, György Lukacs and others see the market as a self-reproducing subsystem, for which the boundaries can only be provided by a tight legal framework (e.g. Sutton 1998). On the other side of the political spectrum, libertarians like Friedrich von Hayek, Milton Friedman and Alec Nove will describe the market as a complex information network that is driven by price information within a legal framework. Moral actors in the market are not mentioned in either of the two perspectives. Expecting moral reflexion from market participants is not only naive, it is also unnecessary given a sufficiently strong regulatory framework around the market.

Business ethics brought a totally different perspective in this intellectual debate. The big debates about the distinctiveness of "the economic system" were set aside by business ethicists, and replaced by micro studies about the actions of companies and business leaders in very specific situations. The focus moved from a dual view towards a triadic relationship between market, state and individual actors. Business 
ethics starts from a number of propositions: (1) morality is inherent to the market, and a competitive free market requires of its participants that they adhere to a number of moral demands; (2) the legal framework supports these requirements but can never be effective unless the market participants themselves are convinced of the usefulness of this regulation, and take them into account in their actions; (3) since there is morality in the market, there is moral freedom and thus there are companies and business leaders that function better or worse from a moral point of view; (4) it is thereby possible to examine under what conditions a company and its participants function morally and support or undermine society (Van Liedekerke, Dubbink 2008).

Born on American campuses in the 1970s, business ethics came to Europe in the $1980 \mathrm{~s}^{1}$, where it formed a counterweight to the dominant, institutional analysis of the market, and set focus on free choice and moral responsibility of the individual. People choose, people decide and their decisions have consequences for everyone. A central element in business ethics education, is the micro analysis of case studies in which decisions of actors are decisive in the ethical performance of companies, whether positive or negative. Business ethics academics tried to identify under which circumstances companies are performing within moral boundaries, through the analysis of hundreds of case studies and identification of best practices. Eventually, the answer to such issues cannot (solely) be provided by philosophers. Therefore, social scientists were involved in business ethics, and over time the ethical perspective was surpassed by organisational sociology, organisational psychology, strategy and other social science domains. On the one hand, the result is that business ethics today is a multidisciplinary science in which the purely ethical dimension seems to be marginally present. On the other hand, it led to a spectacular growth of the discipline. The introduction of social sciences also changed the research themes. It is no longer about controlling and protecting moral boundaries but much more about how we can incorporate companies in society where the economic requirements are increasingly connected to long term societal

\footnotetext{
${ }^{1}$ Society for Business Ethics (SBE), the American organisation for business ethicists, was founded in 1980. The European Business Ethics Network (EBEN), its European counterpart, was founded in 1987.
} 
requirements. The main research topic nowadays is the sustainable enterprise, and the Holy Grail is to demonstrate the business case for corporate sustainability, e.g. why would it make sense from an economic point of view to take people, planet and profit into account? It is clear that these problems are truly multi- and interdisciplinary, it results in a situation where business ethics, ethical entrepreneurship, corporate social entrepreneurship, etc., are difficult to position in the disciplinary structure of our universities. It can be positioned in the economic faculty, in business schools but also in philosophy, psychology, sociology, environmental sciences, engineering, product development etc. A successful research group focusing on sustainable entrepreneurship would have to bring together people from all backgrounds in one institute, and this seems to be an undertaking that has seldom been successful. In a timeframe where societal challenges are increasingly characterised as "super wicked problems" (Levin et al. 2012), interdisciplinary studies are needed, yet remain a sore spot in our university landscape.

The transition from business ethics toward sustainable entrepreneurship took place in the 1990s, and marginalised the role of the ethicist. In the same period the movement around Higher Education for Sustainable Development (HESD, also referred to as Sustainable Higher Education, Lambrechts et al. 2018) surfaced. In the wake of the Brundtland report and the resulting growing attention to sustainability, higher educational institutions also started initiatives to encourage the integration of sustainability (e.g. Dernbach 2002; Lozano et al. 2013). The Talloires Declaration from 1990 is an early example, in which twenty-two (mostly American) universities decided to give a greater role to sustainability in their organization. Several other declarations and charters followed in the 1990s, but the actual breakthrough for HESD followed in the $21^{\text {st }}$ Century. The Association for the Advancement of Sustainability in Higher Education (AASHE) organised its first official meeting in 2006. Common themes that are reflected in the different charters and declarations are: the interdisciplinary character of sustainability; the need to encourage systemic thinking; strengthening partnerships with external stakeholders (companies, governments, non-governmental organizations); greening of campus operations; the moral obligation of universities to contribute to the societal transition toward 
sustainability. Although the connection between corporate sustainability and HESD is clear, and one would suspect them to be closely intertwined, in reality the two research themes developed next to each other and without much interaction. However, they share the same problems and strive for the same solutions: focus on interdisciplinary studies, integrated thinking, and looking beyond the short term and local interests. Both would also benefit from case based education, allowing teachers to illustrate the multidimensional nature of problems and demonstrate how these dimensions influence each other. Furthermore, both aim at shaping and preparing integrated/systemic decision makers, that are able to think multi- and interdisciplinary. The challenge is how to form such leaders without falling into fully diluted and superficial disciplinary education.

In this discussion, the position of ethics remains unclear, it seems marginalised, yet not totally unimportant. The social scientists that transformed "business ethics" as an academic discipline into "sustainable entrepreneurship" seems to forget that the choice to implement sustainability is in the end always a moral choice. Management academics often try to frame sustainable entrepreneurship in line with the economic necessity and strategic importance, but in the end this is just a legitimizing discourse for what is a fundamentally a normative choice. This becomes obvious in cases where sustainable entrepreneurship does not seem to create value at all. For example, what if there is no business case for banning child labour from a supply chain? Normative issues will always be present in business, and business leaders will need to make moral choices in their actions. Those who choose for sustainable business, make this decision because they find it important.

A similar situation can be found in the world of HESD. Again, there are many good reasons to integrate sustainability in higher education, but fundamentally it remains an ethical commitment. Universities prepare the future business leaders, politicians, citizens, consumers, and carry therefore an important responsibility in preparing these future leaders. HESD chooses to prepare people for their role within the complexity and uncertainty of sustainability issues, thereby focusing (among others) on systems thinking, anticipatory thinking, normative competences (Lambrechts et al. 2013), as well as advanced critical and interpretational competences (Lambrechts et al. 2018). HESD seems to be the logical way forward if 
we want to transition towards a sustainable society. It is the environment in which our future business leaders should learn about sustainable entrepreneurship and the structure of wicked problems. This book contains many interesting contributions about how HESD should look like coming from scholars with diverse backgrounds in social science but in the end the choice to aim for HESD, the fundamental step to take this direction and not any other, remains an ethical choice and one that is unavoidable if we still want to have a future.

\section{References}

Dernbach J.C. (ed.) (2002), Stumbling toward sustainability, Environmental Law Institute, Washington.

Lambrechts W., Van Liedekerke L., Van Petegem P. (2018), Higher education for sustainable development in Flanders. Balancing between normative and transformative approaches, „Environmental Education Research”, vol. 24 no. 9, pp. 1284-1300.

Lambrechts W., Mulà I., Ceulemans K., Molderez I., Gaeremynck V. (2013), The integration of competences for sustainable development in higher education. An analysis of bachelor programs in management, ,Journal of Cleaner Production”, vol. 48, pp. 65-73.

Levin K., Cashore B., Bernstein S., Auld G. (2012), Overcoming the tragedy of super wicked problems. Constraining our future selves to ameliorate global climate change, „Policy Sciences”, vol. 45 no. 2 , pp. $123-152$.

Lozano R., Lukman R., Lozano F.J., Huisingh D., Lambrechts W. (2013), Declarations for sustainability in higher education. Becoming better leaders, through addressing the university system, „Journal of Cleaner Production”, vol. 48, pp. 10-19.

Sutton J.F. (1998), Disembodied capitalism. Habermas conception of the economy, „Sociological Forum", vol. 13 no. 1, pp. 61-83.

Tawney R. (1998), Religion and the rise of capitalism, Transaction Publishers, New Jersey.

Van Liedekerke L., Dubbink W. (2008), Twenty years of European business ethics - past developments and future concerns, „Journal of Business Ethics”, vol. 82 no. 2, pp. 273-280.

Vogel D. (2005), The market for virtue, Brookings Institution Press, Washington, DC. 